\title{
PREKRŠAJNO PRAVO U SLUŽBI SUZBIJANJA ZLOUPORABE DROGA U REPUBLICI HRVATSKOJ: POSJEDOVANJE DROGE BEZ NAMJERE STAVLJANJA U PROMET
}

Sažetak: $\quad$ Kad je riječ o suzbijanju zlouporabe droga, odabir državne reakcije uvjetovan je različitim okolnostima, no težnja za učinkovitošću primarni je lajtmotiv. Načini zabrane podrazumijevaju pravne mehanizme i sankcije, a u Republici Hrvatskoj ti mehanizmi pripadaju kaznenom i prekršajnom pravu. Predmet je ovog rada usredotočen na prekršajno pravo s obzirom na značajnu novinu koja je u Republici Hrvatskoj predstavljena prije nekoliko godina: posjedovanje je droge bez namjere stavljanja u promet izostavljeno iz kaznenopravnog mehanizma i prepušteno prekršajnoj sferi. Međutim, odabrano rješenje sadrži i nekoliko otvorenih pitanja. Na ta pitanja dajemo odgovore u ovom radu, nastojeći pristupiti im na holistički način. Prikazujemo legislativne pozicije uzimajući u obzir prethodne spoznaje $i$ etiologiju prihvaćenog rješenja, predstavljamo zastupljenost zlouporabe droge $u$ društvu te provođenjem istraživanja relevantnih presuda otkrivamo stavove judikature propitujući svrhovitost usvojenog rješenja.

Ključne riječi: $\quad$ zlouporaba droga, prekršajno pravo, posjedovanje droge za osobnu uporabu, prekršajno sankcioniranje, kazneno pravo

\footnotetext{
* Dr. sc. Barbara Herceg Pakšić, docentica na Pravnom fakultetu Sveučilišta Josipa Jurja Strossmayera u Osijeku, Stjepana Radića 13, 31000 Osijek. Adresa e-pošte: bherceg@pravos.hr. ORCID: https://orcid.org/0000-0002-7052-928X.

** Nikolina Kovač, mag. iur., Borisa Papandopula 36, 43000 Bjelovar. Adresa e-pošte: nikolina.kovac121@gmail.com. ORCID: https://orcid.org/0000-0001-5549-4579.
} 


\section{O ULOZI PREKRŠAJNOG PRAVA U PODRUČJU ZLOUPORABE DROGA}

Ured za droge Ujedinjenih naroda recentno procjenjuje kako 275 milijuna ljudi koristi neku vrstu droge, a 30,5 milijuna je ovisno o njima, dok je samo desetljeće ranije ta brojka bila osjetno niža. ${ }^{1}$ Zlouporaba je droga u jednom aspektu visoko lukrativna, dok u drugom dovodi do nemjerljive društvene štete. ${ }^{2}$ Posljedično, odabir je prikladnog rješenja vezanog uz uspješnu prevenciju i suzbijanje zlouporabe droge u središtu pozornosti na globalnoj razini te nužno uključuje prekršajnopravne i kaznenopravne odredbe, ali i uspješnu međunarodnu suradnju. ${ }^{3}$ Odabrana suvremena rješenja uvelike su uvjetovana tradicionalnim stavovima društva spram zlouporabe droga, no istovremeno i novijim kretanjima u europskim pravnim sustavima. Hrvatski je predmetni pravni sustav izložen različitim promjenama i novim idejama koje utječu na djelomičnu dekriminalizaciju opojnih droga, što ima praktičnu vrijednost jer učestalost zlouporabe droge u kaznenoj i prekršajnoj praksi nije zanemariva. ${ }^{4}$ Iako kaznena represija ima nezaobilaznu ulogu u suzbijanju kriminaliteta droga, izmjenom Kaznenog zakona iz 2011., (dalje u tekstu KZ), obavljenoj tijekom njegova vaccatio legis, posjedovanje je droge bez namjere stavljanja u promet dekriminalizirano i prepušteno isključivo prekršajnoj sferi. Ta sfera podrazumijeva povrede javnog poretka, društvene discipline ili drugih društvenih vrijednosti isključenih iz kaznenopravne zaštite. ${ }^{6}$ U sadržajnom smislu, razlika između prekršaja i kaznenog djela, sukladno vladajućem stavu je kvantitativne naravi, ogleda se u jačini ugrožavanja ili u stupnju povrede, a ne u bitnom

1208 milijuna, odnosno 26 milijuna ovisnika o drogama. World Drug Report, Pre-briefing to the Member States, UNODOC Vienna 2018. Trends in global drug use, str. 7. URL=https://www.unodc.org/wdr2018/prelaunch/Pre-briefingAM-fixed.pdf. Pristupljeno 10. srpnja 2018.

2 Na globalnoj razini, smrt prouzročena uzimanjem droge povećala se za 60\% 2015. godine u odnosu na 2000. godinu. Među rizične se faktore ubrajaju traume i problemi u djetinjstvu (zlostavljanje i zanemarivanje djeteta), psihički zdravstveni problemi, siromaštvo, dostupnost droge i društveno okruženje koje joj je sklono, negativno školsko ozračje. Cf. ibid., str. 9. i 30.

3 Uključivanjem u međunarodne aktivnosti Republika Hrvatska nastoji što aktivnije sudjelovati u rješavanju problematike droga, kreiranjem politike i stručnih pristupa. Neke od važnijih suradnji s međunarodnim organizacijama i institucijama vezane su uz UN-ov Ured za droge i kriminal, Komisiju za opojne droge, Međunarodni odbor za kontrolu narkotika, Svjetsku zdravstvenu organizaciju, Pompidou grupu Vijeća Europe, agencije Europske unije (Europol, EMCDDA), i druge. Isto tako, potpisnica je brojnih relevantnih međunarodnih akata na području suzbijanja zlouporabe droge, primjerice UN-ove Jedinstvene konvencije o opojnim drogama (New York, 1961.), Protokola o izmjenama Jedinstvene konvencije o opojnim drogama (Ženeva, 1972.), Konvencije Ujedinjenih naroda protiv nedozvoljenog prometa i psihotropskim supstancama (Beč, 1988.) i UN-ove Konvencija o psihotropnim tvarima (Beč, 1971.).

4 Nikšić iznosi da je riječ o jednom od najzastupljenijih kaznenih i prekršajnih djela. Nikšić, S., Prekršajna djela zlouporabe droga i učinci nakon dekriminalizacije kaznenog djela posjedovanja droge bez namjere njezina stavljanja u promet te osvrt na neke aspekte Prekršajnog zakona, Hrvatski ljetopis za kazneno pravo i praksu, Zagreb, god. 21, br. 2, 2014., str. 630.

5 Narodne novine, broj 144/2012.

6 Za razliku od nekih drugih zemalja, primjerice Francuske koja njeguje povezanost prekršajnog i upravnog prava, Republika Hrvatska u najvećoj mjeri slijedi njemački sustav sukladno kojem prekršaji pripadaju kaznenom pravu u širem smislu. Ovo je prevladavajuće stajalište u relevantnim djelima hrvatskih autora. Primjerice, Novoselec, P., Opći dio kaznenog prava, Osijek, 2016. str. 38.-39., Bonačić, M.; Rašo, M., Obilježja prekršajnog prava i sudovanja, aktualna pitanja i prioriteti de lege ferenda, Hrvatski ljetopis za kazneno pravo i praksu, Zagreb, god. 19, br. 2, 2012., str. 439. U tom kontekstu se i standardi zaštite ljudskih prava i sloboda primjenjivi u kaznenom pravu trebaju primjenjivati i u prekršajnom pravu. Takav stav odavno primjenjuje i Europski sud za ljudska prava. Primjerice, u sukladno stavu izraženom u predmetu Engel i drugi protiv Nizozemske 5100/71; 5101/71; 5102/71; 5354/72; 5370/72, još od 8. lipnja 1976., ispunjenje određenih kriterija optužbe može dovesti do toga da se konvencijski učinci prenose i na prekršajno pravo, a 21. veljače 1984. ovaj sud predmetu Öztürk protiv Njemačke, 8544/79, u par. 53 ističe kaznenu narav prekršaja, opisujući opću narav i svrhu zapriječene sankcije kao "deterrent and punitive". Također, u prosudbi naravi sankcija važna je i presuda u predmetu Ezeh i Connors protiv Ujedinjenog Kraljevstva, 39665/98 i 40086/98 od 9. listopada 2003. osobito para. 85, 105 i 106. 
razlikovanju zaštićenih vrijednosti ${ }^{7}$ pri čemu se izbor kaznene ili prekršajne sankcije pripisuje ocjeni zakonodavca kriminalno-političke naravi. S druge strane, pojedini autori prigovaraju "preharmoniziranosti" s kaznenim pravom te ističu načelo razmjernosti kao temeljnu razliku između prekršajnog i kaznenog sustava (između važnosti zaštićenog dobra, zapriječene kazne te ograničenja prava) koje zahtijeva složenije forme postupanja u kaznenom postupku radi snažnijih jamstava zaštite ljudskih prava i spoznajnih procesa. ${ }^{8}$

Prethodno navedenoj izmjeni, predmetno djelo je bilo dvostruko kažnjivo - kroz uspostavu kaznene i prekršajne odgovornosti, ${ }^{9}$ a potom je ostavljeno samo prekršajnoj sferi. Tim je rješenjem prekršajno pravo značajno dobilo na važnosti, a kazneno pravo na ekskluzivnosti, sukladno načelu ultima ratio. O razlozima ovog opredjeljenja promišljamo kroz sadržajnu i formalnu etimologiju. U potonjem kontekstu, jedan od najsnažnijih argumenata pozitivne regulacije bilo je dosljedno poštovanje pravila ne bis in idem, odnosno zabrane dvostrukog suđenja po istoj stvari. Dotadašnje dvostruko inkriminiranje bilo je suprotno načelu izraženom u čl. 31. st. 2. Ustava Republike Hrvatske ${ }^{10}$ te čl. 4. Protokola 7 uz Konvenciju za zaštitu ljudskih prava i temeljnih sloboda (engl. right not to be tried or punished twice). ${ }^{11}$ Europski je sud za ljudska prava dao svoj obol u ovoj tematici osudivši Republiku Hrvatsku za dvostruka postupanja nastala povodom dvostruke legislative u slučajevima Maresti, a potom i Tomasović ${ }^{12}$ čime je izvršen značajan utjecaj europskog prava na prekršajno, no ujedno i na kazneno pravo. ${ }^{13} \mathrm{Ne}$ bis in idem proklamirano je i mnogim međunarodnim aktima ${ }^{14}$ te se smatra suvremenim dosegom ljudskih prava koje

7 Jescheck, H.-H.; Weigend, T., Lehrbuch des Strafrechts, Allgemeiner Teil, Berlin, 1996., str. 59., Novoselec, Opći dio kaznenog prava, loc. cit., Nikšić, op. cit. u bilj. 4, str. 621.

8 Josipović, I., Novi prekršajni zakon: konačno, reformski iskorak, u: I. Josipović, M. Rašo, Prekršajni zakon, Zagreb, Narodne novine, 2008., str. 11.

9 Do stupanja na snagu KZ-a, odnosno do 1. siječnja 2013., riječ je bila o kaznenom djelu (članak 173. stavak 1. KZ-a/97) te prekršaju (čl. 54. st 1. t. 1. i st. 2. i 3. Zakona o suzbijanju zlouporabe droga).

10 Ustavni zabrana ne bis in idem onemogućava ponovno suđenje ili kažnjavanje u kaznenom postupku za djelo s prethodno pravomoćnim oslobođenjem ili osudom. Ustav Republike Hrvatske, Narodne novine, broj 56/1990, 135/1997, 113/2000, 28/2001, 76/2010, 5/2014.

11 Konvencijska zabrana ne bis in idem onemogućava ponovno suđenje ili kažnjavanje u kaznenom postupku iste države za kazneno djelo s prethodnim pravomoćnim oslobođenjem ili osudom, no nije spriječeno ponovno razmatranje slučaja u skladu sa zakonom i kaznenim postupkom u slučaju novih dokaza ili činjenica ili je u prethodnom postupku došlo do bitnih povreda koje su mogle utjecati na rješenje slučaja. Odredbe nisu derogabilne temeljem članka 15. Konvencije. Konvencija za zaštitu ljudskih prava i temeljnih sloboda te Protokola br. 1, Protokola br. 4, Protokola br. 6 te Protokola br. 7 uz tu Konvenciju, Narodne novine Međunarodni ugovori, broj 6/1999.

12 Maresti protiv Hrvatske, 55759/07, 25. lipnja 2009. (radilo se o prekršaju protiv javnog reda i mira i kaznenom djelu nanošenja teške tjelesne ozljede), Tomasović protiv Hrvatske, zahtjev 53785/09, 18. listopada 2011. (prekršajna i kaznena odgovornost za posjedovanje droge bez namjere njezina stavljanja u promet). Kritički o ovim presudama vidjeti Josipović, op. cit. u bilj. 8, str. 9.

13 O značaju presude Maresti u kontekstu predmetne problematike vidjeti Turković et al., Komentar Kaznenog zakona, Narodne novine, 2013., str. 9. Kao rezultat, iz kaznenih je odredbi izbrisan raniji čl. 63. st. 2. vezan uz uračunavanje prethodne prekršajne kazne u kaznu za kazneno djelo, dok je određeni broj kaznenih djela analiziran upravo u kontekstu preklapanja opisa s prekršajnim djelima. To je rezultiralo brisanjem nekih djela (npr. temeljni oblik bespravne gradnje), prebacivanjem nekih djela potpuno u prekršajnu sferu (posjedovanje droge bez namjere stavljanja u promet) ili specifičnim inkriminacijskim rješenjem koje je uključivalo "raspoređivanje" u druga kaznena djela (nasilje u obitelji, koje je nakon prvotnog brisanja vraćeno u kazneni korpus u specifičnom obliku).

14 Primjerice, Međunarodni pakt o građanskim i političkim pravima, Protokol 7. uz Konvenciju o zaštiti ljudskih prava i temeljnih sloboda, Europska konvencija o izručenju iz 1957. i Dopunski protokol iz 1975., Konvencija o pranju, traganju, privremenom oduzimanju i oduzimanju prihoda stečenog kaznenim djelom iz 1990., Konvencija o provedbi Schengenskog sporazuma, Konvencija o zaštiti financijskih interesa iz 1995. (PIF konvencija) i Povelja o temeljnim pravima Europske unije od 12. prosinca 2007. Europski sud pravde u Luksemburgu priznao je načelo kao načelo europskog pravnog poretka, a o tome više vidjeti Ivičević Karas, E., Načelo ne bis in idem u europskom kaznenom pravu, Hrvatski ljetopis za kazneno pravo i praksu, Zagreb, god. 21, br. 2, 2014., str. 282. et seq. 
ujedno i jamči pravnu sigurnost. ${ }^{15}$ Nakon značajnih predmeta Europskog suda za ljudska prava, primjerice Zolotukhin, Engel i drugih koje zbog limitiranosti opsega rada ne navodimo, presuda A. i B. protiv Norveške donijela je novine u načinu tumačenja ovog načela. ${ }^{16}$ Danas je i odredbom Prekršajnog zakona propisano isključenje primjene prekršajnog zakonodavstva u posebnim slučajevima. ${ }^{17}$ Dodatno, europski su se trendovi na ovom području izmijenili u smjeru dekriminalizacije. Analiza obavljena tijekom rada na predloženom zakonskom rješenju pokazala je kako u Španjolskoj, Portugalu, Italiji, Belgiji, Luxemburgu, Sloveniji posjedovanje droge "za vlastite potrebe" nije kazneno djelo, da se za prvo posjedovanje marihuane za vlastite potrebe u Irskoj ne kažnjava, a Nizozemskoj tolerira posjedovanje lakih droga za vlastite potrebe do 5 grama. ${ }^{18}$ Mogućnost odabira regulacije posjedovanja droga za vlastitu uporabu ne protivi se pravilima Europske unije. ${ }^{19} \mathrm{~S}$ obzirom na načelno visok broj procesuiranih kaznenih djela iz područja kri-

15 Ova je tematika, a poglavito nakon navedenih presuda, bila predmet opsežnih analiza u hrvatskom pravu. U tom smislu zainteresiranog čitatelja upućujemo na sljedeće izvore: Bonačić, M.; Tomašić, T., Implementacija standarda Europskog suda za ljudska prava u hrvatskom prekršajnom pravu i praksi, Hrvatski ljetopis za kaznene znanosti i praksu, Zagreb, god. 24, br. 2, 2017., str. 381.-411.; Novosel, D.; Rašo, M.; Burić, Z., Razgraničenje kaznenih djela i prekršaja u svjetlu presude Europskog suda za ljudska prava u predmetu Maresti protiv Hrvatske, Hrvatski ljetopis za kazneno pravo i praksu, vol. 17, br. 2, 2010., str. 785.-812. Derenčinović, D.; Gulišija, M.; Dragičević Prtenjača, M., Novosti u materijalnopravnim odredbama Prekršajnog zakona, Hrvatski ljetopis za kazneno pravo i praksu, god. 20, br. 2, 2013., str. 751.-777.; Ivičević Karas, E.; Kos, D., Primjena načela ne bis in idem u hrvatskom kaznenom pravu, Hrvatski ljetopis za kazneno pravo i praksu, god. 19, br. 2, 2012., str. 555.-584.; Josipović, I.; Novak Hrgović, K., Načelo ne bis in idem u kontekstu prekršajnog, kaznenog i upravnog prava, Hrvatski ljetopis za kaznene znanosti i praksu, god. 23, br. 2, 2016., str. 469.-507.

16 A. i B. protiv Norveške, 24130/11 i 29758/11 od 15. studenog 2016. Podnositelji su tvrdili da su obojica dva puta suđeni i kažnjeni u kontekstu poreznog kažnjavanja te su u pitanju bili kazneni i upravni postupak. Sud je sa šesnaest glasova prema jednom presudio kako nije riječ o povredi. Kad je riječ o ovoj presudi, možemo reći da je donijela svojevrsno relativiziranje dotadašnjeg tumačenja ne bis in idem načela, pri čemu su poglavito zanimljiva objašnjenja iz paragrafa 121. i 123. u kojima se navodi da bi države trebale imati mogućnosti legitimno odabrati komplementarne pravne odgovore putem različitih postupaka koji čine povezanu cjelinu (pod uvjetom da ukupnost odgovora nije prekomjeran teret za pojedinca) te se ne brani zauzimanje "integriranog" pristupa, a posebice usporedni stadiji pravnog odgovora na nedjela od strane različitih tijela i u različite svrhe.

17 Upravo radi onemogućavanja konsekutivnog vođenja kaznenog i prekršajnog postupka za isto djelo 22. ožujka promijenjen je čl. 10. sukladno kojem ako je protiv počinitelja prekršaja započeo kazneni postupak zbog kaznenog djela kojim je obuhvaćen i prekršaj, ne može se za taj prekršaj pokrenuti prekršajni postupak, a ako je postupak pokrenut ne može se dalje voditi. Prekršajni zakon, Narodne novine, broj 107/2007, 39/2013, 157/2013, 110/2015, 70/2017, 118/2018.

18 Turković et al., op. cit. (bilj. 13), str. 9.-10. Isti izvor dodatno navodi kako je u Njemačkoj Ustavni sud 1994. donio odluku da državni odvjetnik može odustati od progona kod povremenog osobnog uživanja droge, ako je pronađena mala količina te nema opasnosti za druge. U Danskoj postoji uputa zakonodavca još iz 1971. sukladno kojoj namjera zakonodavca nije bila inkriminirati korištenje i posjedovanje droge za vlastite potrebe. U Francuskoj je 1999. usvojena Direktiva da prioritet kod posjedovanja droge za vlastite potrebe treba dati tretmanu, a ne kažnjavanju. Isti su podaci ove poredbenopravne analize dani u prijedlogu novog rješenja te sadržani u nacrtu Prijedloga o izmjenama i dopunama Kaznenog zakona iz listopada 2012. Dostupno na URL=https://pravosudje.gov.hr/posjedovanje-droge-za-osobnu-uporabu-prekrsajno-a-ne-kazneno-djelo/6388. Pristupljeno 11. veljače 2019. Još 2003. godine, analize europskih legislativa od strane Europskog centra za praćenje droga i ovisnosti o drogama ( EMCDDA) pokazale su da je u većini zemalja količina temeljni kriterij za razliku između posjedovanja i prodaje te za određivanje kazne. Detaljnije u publikaciji The State of Drugs problem and in the European Union and Norway, European Monitoring Centre for Drugs and Drugs Addiction. Luxembourg: Office for Official Publications of the European Communities, 2003., str. 33.-34. Recentne trendove po pitanju droga čitatelj može pronaći u publikaciji Europsko izvješće o drogama - trendovi i razvoj, Luksemburg, Ured za publikacije Europske unije, 2019.

Veći broj zemalja količinu u zakonu razrađuje na malu i veliku, ostavljajući policiji ili sudovima mogućnost procjene, dok dio zemalja ima pak točno propisane količine. Neke zemlje uzimaju novčanu vrijednost droge kao bazu, neke količinu aktivne supstance u zaplijenjenom materijalu, a neke kao i RH tu količinu ostavljaju na prosudbu suda. Razlike od zemlje do zemlje su velike, pa je taj raspon za marihuanu među zemljama od 0,3 pa sve do 60 grama. Detaljnije vidjeti Posjedovanje ili prodaja: koliko grama teži osobna uporaba?, URL=http://www.novilist.hr/Vijesti/Hrvatska/Posjedovanje-ili-prodaja-Koliko-grama-teziosobna-uporaba?meta -refresh=true. Pristupljeno 13. srpnja 2018.

19 Prema Okvirnoj odluci Vijeća 2004/757/PUP od 25. listopada 2004. o utvrđivanju minimalnih odredaba vezanih za elemente kaznenih djela i sankcija u području nezakonite trgovine drogom, SL L 335, 11. studenoga 2004., potencirano je djelovanje Europske unije na najteža kaznena djela vezana za drogu te isključenje određenih vrsta ponašanja vezanih za osobnu potrošnju iz područja primjene ove Okvirne odluke ne predstavlja smjernicu Vijeća o tome kako bi države članice trebale postupati u drugim takvim slučajevima u okviru svojih nacionalnih zakonodavstava. 
minaliteta droga, istaknut je i argument rasterećenja kaznenih sudova i državnog odvjetništva koji bi se mogli posvetiti progonu drugih vrsta kaznenih djela.

Sadržajna etiologija odabranog rješenja vezana je uz brojne prednosti koje liberalniji pristup nudi: prekršajni je postupak brži i fleksibilniji od kaznenog, nudi i tretmanski pristup kroz zaštitne mjere, činjenica osude ne nosi toliku društvenu stigmu, a izostanak upisa u kaznenu evidenciju olakšava kasnije društveno funkcioniranje (pronalazak posla i slično). Potom, kazneno sankcioniranje "stila života" (skitnja, uživanje alkohola, uživanje droge, obavljanje prostitucije) zastario je pristup te se u takvim situacijama prekršajna reakcija smatra dostatnom i razmjernom. Iznesen je i argument kako bi se uštede sredstava mogle usmjeriti na liječenje ovisnika i pomoć obiteljima u borbi s drogom. ${ }^{20}$

Predmet ovog rada jesu otvorena pitanja vezana uz hrvatsko rješenje o posjedovanju droge bez namjere stavljanja u promet ("namijenjene osobnoj uporabi") i oživotvorenje prekršajno-pravnog sankcioniranja. S obzirom na to da je predmetna zakonska odredba izostavila pitanja vrste i količine droge i prepustila ih sudskoj praksi (razloge analiziramo niže u pripadajućem poglavlju), postavljamo sljedeća istraživačka pitanja: Koja se vrsta droge pojavljuje u prekršajnim presudama? Koja se količina droge pojavljuje u pojedinim slučajevima? Koja su socioekonomska obilježja počinitelja? Kakva je politika kažnjavanja s obzirom na raspon predviđene kazne? Legislativnom analizom, uvrštavanjem recentnih znanstvenih spoznaja po pitanju odabranog kriminaliteta droga kao i relevantnih sudskih sentenci te prikazivanjem rezultata vlastita istraživanja dajemo odgovore na postavljena pitanja. Polazne su autorske pretpostavke da će se u istraženim slučajevima pojavljivati isključivo male količine lakog tipa droge od strane mlađih počinitelja (vjerojatno muškog spola), koji će biti kažnjavani u rasponu predviđene novčane kazne. Unaprijed je teško predviđati točne iznose jer oni ovise o specifičnim okolnostima in concreto, no vjerujemo da se predviđeni kazneni okvir u cijelosti iskorištava. Odgovore na ova pitanja dajemo u zaključku rada pri čemu je krajnji cilj, pored istraživanjem dobivenih spoznaja, dati ocjenu o tome je li predviđeno zakonsko rješenje poslužilo svrsi koja je uvođenjem promovirana.

\section{ZASTUPLJENOST UZIMANJA DROGA I LEGISLATIVNE ZABRANE - POČECI, EVOLUCIJA I REVOLUCIJA}

Počeci suzbijanja na teritoriju Republike Hrvatske javljaju se oko 1969. godine uz tadašnji vladajući stav da se radi o rijetkom i ekstravagantnom problemu. ${ }^{21} \mathrm{~S}$ vremenom se na teritoriju Hrvatske povećavala vrsta dostupnih droga pa se tako uz kanabis, pojavljuju opijati i sintetičke

20 Detaljnije, URL=https://pravosudje.gov.hr/posjedovanje-droge-za-osobnu-uporabu-prekrsajno-a-ne-kazneno-djelo/6388. Pristupljeno 11. veljače 2019.

21 Klarić, D., Droga i kriminal: važni metodički pristupi suzbijanja, Udruga “Znanje daje sigurnost”, Zagreb, 2008., str. 234.-235 U poredbenom smislu, problematici povijesnog razvijanja konzumiranja droge i prikladnog odgovora posvećena je značajna pozornost. Navodi se tako da je Weimarska Republika smatrana razdobljem u kojem se konzumiralo mnogo droge te je prvi put konzumacija orijentirana na uživanje droga ocijenjena problematičnom. Odlučujućim datumom u interpretaciji tzv. opojnog zakonodavstva (Betäubungsmittelgesetzgebung) smatra se 1. siječnja 1921., kada je Selling predstavio stajalište prema kojem je Njemačka od 1919. nevoljko integrirana u sustav međunarodne trgovine drogom. Vidjeti u Hoffman, A., Drogenkonsum undkontrolle, Zur Etablierung eines soziales Problems im ersten Drittel des 20. Jahrhunderts, Springer Fachmedien, Wiesbaden, 2012. str. 11. te 79.-80. 
droge. ${ }^{22}$ Razmatran je i utjecaj ratnog stanja na porast ovisnosti o drogama, ${ }^{23}$ a istraživanje provedeno 1998. godine otkrilo je raširenost uporabe sedativa među adolescentima, poglavito u dijelovima središnje i istočne Hrvatske koja je najviše izložena ratnim stradanjima. ${ }^{24}$ Dodatno, porast konzumacije droge tijekom devedesetih godina povezuje se i s razdobljem tranzicije. ${ }^{25}$

Usporedbom podataka protekom gotovo četiri desetljeća pokazuje se zanimljiva slika. Naime, 1981. godine, evidentirano je tek 99 tadašnjih kaznenih djela vezanih za zlouporabu droga ${ }^{26}$ dok su prema recentnim podacima za 2017. godinu, 4.604 osobe proglašene krivima u prekršajnom postupku za zlouporabu droga. ${ }^{27}$ Proklamirani su nacionalni strateški ciljevi spriječiti i smanjiti zlouporabu droga i sredstava ovisnosti, smanjiti dostupnost droga te rizike povezane s njezinim korištenjem te unaprijediti sustav za suzbijanje. ${ }^{28}$ Sukladno podacima iz Izvješća o provedbi Nacionalne strategije i Akcijskog plana iz 2016. godine, unutar strukture kriminaliteta droga 6.709 djela odnosi se na prekršaje u modalitetu posjedovanja. Istovremeno su u značajno manjoj mjeri zastupljena kaznena djela, ukupno njih 2842 (Omogućavanje trošenja droga iz čl. 191. KZ-a/11 - 558 djela te Neovlaštena proizvodnja i promet drogama iz čl. 190. KZ-a/11 - 2284). Isti dokument ističe lagani porast odraslih počinitelja kaznenih djela zlouporabe droge, (ponovni) porast broja mlađih punoljetnih osoba, dok je broj maloljetnih počinitelja ostao na razini prethodne godine. ${ }^{29}$ Dugoročni statistički pokazatelji tijekom desetogodišnjeg razdoblja (od 1998. pa sve do 2007. godine) pokazuju da je ukupno 28.115 punoljetnih počinitelja prekršaja okrivljeno za zlouporabu opojnih droga, a 19.271 počinitelja proglašeno je krivim. Najčešća izrečena sankcija je novčana kazna, i to 17.185 (89\%). Opomena je izrečena 1.973 počinitelja, a kazna zatvora za 113 počinitelja. ${ }^{30} \mathrm{U}$ istom razdoblju okrivljeno je 3.028 maloljetnih počinitelja prekršaja zlouporabe opojnih droga, a proglašeno je krivima njih 1.444. Najčešće im je izricana odgojna mjera - 1.006 (69,7\%). Novčane kazne izrečene su za 438 maloljetnih počinitelja. ${ }^{31}$ Zanimljivo je promotriti i usporedbu prekršajne i kaznene odgovornosti. Naime, u prvoj polovini promatranoga desetogodišnjeg razdoblja (tj.

22 Takva je situacija utjecala na smrtne ishode uvjetovane drogama - 1979. godine bilježi osam smrtnih slučajeva od predoziranja heroinom, dok je 1981. taj broj porastao na dvanaest te proizvodnju i krijumčarenje. Primjerice, na širem području Zagreba bilježi se 36 zasada plantaže indijske konoplje radi dobivanja marihuane. Ibidem.

23 Dubreta, N., Društvo i odnos prema drogama: sociokulturni kontekst upotrebe kanabisa, Hrvatska sveučilišna naklada: Pučko otvoreno učilište, Zagreb, 2005., str. 181.-183.

24 Sakoman, S.; Raboteg-Šarić, Z.; Kuzman, M., Raširenost zlouporabe sredstava ovisnosti među hrvatskim srednjoškolcima, Društvena istraživanja, god. 11, br. 2-3 (58-59), 2002., str. 331.-334.

25 Dubreta, N., Društvo i odnos prema drogama: sociokulturni kontekst upotrebe kanabisa, loc. cit.

26 Klarić, op. cit. u bilj. 21, str. 237.

27 Državni zavod za statistiku, Počinitelji prekršaja u 2017., Statistička izvješća 1629, Zagreb 2018., str. 15.

28 Nacionalna je strategija kao temeljni dokument poslužila i kao osnova za donošenje zakonskih i podzakonskih propisa iz područja suzbijanja zlouporabe droga te kao osnova za izradu godišnjih Akcijskih planova suzbijanja zlouporabe droga i provedbenih programa iz tog područja. Nacionalni program Suzbijanja zlouporabe droge, Ministarstvo unutarnjih poslova. URL=https:// www.mup.hr/public/documents/Nacionalni\%20programi/Nacionalni\%20program\%20\%20Suzbijanje\%20zlouporabe\%20 droga.pdf. Pristupljeno 22. kolovoza 2018. Prvu Nacionalnu strategiju nadzora nad drogama, suzbijanja zlouporabe droga i pomoći ovisnicima o drogama u Republici Hrvatskoj donio je Hrvatski sabor 1996. godine.

29 Izvješće o provedbi Nacionalne strategije i Akcijskog plana suzbijanja zlouporabe droga u RH za 2016. godinu, Vlada RH, USZD, Zagreb, 2017., URL=https://drogeiovisnosti.gov.hr/pristup-informacijama/strategije-planovi-i-izvjesca/izvjesca-o-provedbinacionalne-strategije-i-akcijskih-planova/940. Pristupljeno 22. kolovoza 2018. 
od 1998. do 2001.) broj počinitelja prekršaja bio je znatno veći u odnosu na broj počinitelja kaznenog djela zlouporabe opojnih droga. U drugoj polovini istog razdoblja (tj. od 2002. do 2007.) podaci pokazuju da je broj počinitelja kaznenog djela zlouporabe opojnih droga znatno veći od broja počinitelja prekršaja. ${ }^{32}$

Nadalje, podaci dobiveni istraživanjem o uporabi sredstava ovisnosti u općoj populaciji $\mathrm{RH}^{33}$ u 2015. i 2016. otkrivaju kako je (u godini koja je prethodila godini istraživanja) ilegalnu drogu uzimalo $8,3 \%$ osoba (od 15 do 64 godine), pri čemu je najčešće korišten kanabis. $U$ navedenom razdoblju kanabis je uzimalo 7,9\% odraslih i $16 \%$ mlađih odraslih (od 15 do 34 godine), a češće su ga uzimali muškarci nego žene (11,5\% muškaraca i 4,3\% žena). Kanabis je u posljednjih godinu dana uzimala svaka peta osoba u dobi između 15 i 24 godine (19,7\%). Za isto razdoblje, istraživanja provedena u Njemačkoj navode kako otprilike četvrtina odraslog stanovništva ima neku vrstu doticaja s ilegalnim drogama, no više od $74 \%$ Nijemaca nikada nije probalo drogu. U adolescenata, međutim, brojevi variraju. U 2012. godini svaki trinaesti adolescent u dobi od 12 do 17 godina $(7,8 \%)$ u Njemačkoj je konzumirao kanabis barem jedanput u životu (prevalencija tijekom života), 5,6\% od 12 do 17 godina konzumiralo je u posljednjih dvanaest mjeseci prije ispitivanja kanabis (dvanaestomjesečna prevalencija), od čega 1,3\% redovito. ${ }^{34} \mathrm{U}$ novije vrijeme autori se bave i procjenama javnih rashoda u području suzbijanja zlouporabe droga u Republici Hrvatskoj, ${ }^{35}$ a proklamirane mjere za suzbijanje zlouporabe droga orijentirane su na represiju, primarnu i sekundarnu prevenciju te druge mjere. ${ }^{36}$

\subsection{KAZNENOPRAVNA REPRESIJA - PRIMARNO SREDSTVO REAKCIJE}

Nakon osamostaljenja i zakonodavstva iz prethodne države, ${ }^{37}$ Republika Hrvatska usvojila je Kazneni zakon ${ }^{38}$ te u nekoliko navrata mijenjala kazneno zakonodavstvo glede zlouporabe droga. ${ }^{39}$ Neuspio pokušaj dekriminalizacije odvio se prije više od desetljeća i pol, kada se 2003.

32 Ibid.

33 Istraživanje o uporabi sredstava ovisnosti u općoj populaciji Republike Hrvatske provedeno tijekom 2015. i 2016. godine, na inicijativu USZD-a proveo ga je Institut društvenih znanosti "Ivo Pilar". URL=https://drogeiovisnosti.gov.hr/pristupinformacijama/strategije-planovi-i-izvjesca/izvjesca-o-provedbi-nacionalne-strategije-i-akcijskih-planova/940, pristupljeno 22. kolovoza 2018. Tu je i godišnja prevalencija konzumacije nekih novih droga bila $1,3 \%$ za odrasle, a $2,5 \%$ za mlađe odrasle. Najveća prevalencija uzimanja bilo koje nove droge u posljednjih godinu dana (3,6\%) utvrđena je u najmlađoj dobnoj skupini (između 15 i 24 godine).

34 Detaljnije podatke vidjeti u Drogen- und Suchtbericht, Die Drogenbeauftragte der Bundesregierung Bundesministerium für Gesundheit, Berlin, 2015., str. 39.-41.

35 Navodi se gotovo 0,2\% BDP-a, odnosno gotovo 742 milijuna kuna u 2011. godini. Jurlina Alibegović, D.; Slijepčević, S., Procjena javnih rashoda u području suzbijanja zlouporabe droga u Hrvatskoj, Društvena istraživanja: časopis za opća društvena pitanja, god. 24, br. 1, 2015., str. 13.

36 Represija obuhvaća otkrivanje i sankcioniranje, primarna prevencija obuhvaća odgojno-obrazovne programe kroz različite mehanizme društvenog nadzora, a sekundarna prevencija usmjerena je na rano otkrivanje, praćenje, liječenje i resocijalizaciju povremenih konzumenata i ovisnika o drogama.

37 Krivični zakon SFRJ, Službeni list SFRJ, br. 44/1976, 36/1977, 56/1977, 34/1984, 74/1987, 3/1990, 38/1990 preuzet je Zakonom o preuzimanju Krivičnog zakona Socijalističke Federativne Republike Jugoslavije, Narodne novine, broj 53/1991.

38 Kazneni zakon iz 1997, Narodne novine, broj 110/1997, 27/1998, 50/2000, 129/2000, 84/2005, 51/2001, 111/2003, 190/2003, 105/2004, 71/2006, 110/2007, 152/2008, 57/2011, 77/2011, 125/2011, 143/2012, dalje KZ/97.

39 Detaljnije o izmjenama u kaznenoj regulaciji do 2003. godine vidjeti Tripalo, D., Kaznenopravni aspekti zlouporabe droga, Hrvatski ljetopis za kazneno pravo i praksu, Zagreb, god. 10, br. 2, 2003., str. 554. et seq. Dodatno, Cvjetko, B., Kazneno zakonodavstvo i 
godine novelom tadašnjeg KZ-a/97 željelo dekriminalizirati posjedovanje bez namjere stavljanja u promet (namijenjene osobnoj uporabi) Zakonom o izmjenama i dopunama KZ-a/97.40 Promjene koje je donio KZ/11 izazvale su veliku medijsku pozornost. ${ }^{41}$ Poglavito se to odnosi na odredbe vezane uz predmetnu problematiku. Usporedivši prethodni kažnjivi opseg, zakonodavac je prihvatio djelomičnu dekriminalizaciju te je posjedovanje droge za osobnu uporabu prepustio isključivo prekršajnom sankcioniranju. ${ }^{42}$ Potreba za ovim rješenjem bila je podložna polemikama, a istinska dekriminalizacija donekle devalorizirana visokom zapriječenom prekršajnom sankcijom. Svrha je kaznenih odredbi zaštita ljudskog zdravlja, ${ }^{43}$ pa su dva kaznena djela (čl. 190. i čl. 191.) vezana uz zlouporabu droga smještena u Glavi devetnaestoj koja nosi naziv "Kaznena djela protiv zdravlja ljudi”. Prvo djelo, Neovlaštena proizvodnja i promet drogama, primarno je usmjereno na neovlaštenu proizvodnju ili preradu kao i prodaju droge. Primjerice, obilježja ovog djela u pokušaju ostvario je okrivljenik koji je PVC vrećicu s hašišom prevozio prijatelju radi prerade u ulje kanabisa. ${ }^{44}$ Drugo djelo, Omogućavanje trošenja droga, usmjereno je na navođenje na trošenje droge ili davanje droge ili prostora radi trošenja droge. Obilježja ovog kaznenog djela ostvario je okrivljenik koji je pozvao drugu osobu u svoj stan, prethodno pripremivši heroin za intravenoznu uporabu koji je osoba potom i uzela i zapala u komu. ${ }^{45}$ Novost su i specifični oblici kvalifikatornih okolnosti za navedena djela koja se sastoje u tome da se čine prema osobi s težim duševnim smetnjama ili djetetu ili u školi ili na drugom mjestu koje služi obrazovanju, odgoju, sportskoj ili društvenoj aktivnosti djece ili u njegovoj neposrednoj blizini ili u kaznenoj ustanovi. ${ }^{46} \mathrm{U}$ nastavku dajemo tablični prikaz ukupnog broja optuženih i osuđenih osoba u razdoblju od 2010. do 2017. godine za kazneno djelo Zlouporaba droga (čl. 173. KZ-a/97), odnosno Neovlaštena proizvodnja i promet drogama (čl. 190. KZa/11). Kao posljedica dekriminalizacije dijela radnji vezanih uz zlouporabu droga, zamjetan je izraženi pad u godišnjoj brojci optuženih i osuđenih osoba za 2013. godinu kad je KZ/11

kaznenopravna reakcija na kazneno djelo zlouporabe opojnih droga u Republici Hrvatskoj, Hrvatski ljetopis za kazneno pravo i praksu, Zagreb, god. 10, br. 2, 2003., str. 909.-939.

40 Narodne novine, broj 111/2003, međutim ova novela nije stupila na snagu. U to vrijeme pojedini su autori predviđali da bi se time smanjio kriminalitet vezan uz zlouporabu opojnih droga i predstavljao tek od 3 do $4 \%$ ukupnoga kriminaliteta (u odnosu na dotadašnjih 13,5\%.) s obzirom na to da su ostali modaliteti izvršenja djela relativno rijetki. Kozary, D., Zlouporaba opojnih droga, Pravni vjesnik, god. 27, br. 1, 2011., str. 107.-108.

41 Primjerice vidjeti Posjedovanje ili prodaja: koliko grama teži osobna uporaba?, URL=http://www.novilist.hr/Vijesti/Hrvatska/ Posjedovanje-ili-prodaja-Koliko-grama-tezi-osobna-uporaba?meta -refresh=true. Pristupljeno 13. siječnja 2019.

42 Prijedlog zakona o izmjenama i dopunama Kaznenog zakona, Ministarstvo pravosuđa, Zagreb, listopad 2012., str. 4. Kako se navodi u Prijedlogu zakona, zadržavanje i posjedovanje droge za vlastite potrebe samo u prekršajnom zakonodavstvu nije od utjecaja na ostale oblike ovog kaznenog djela u smislu kaznenog progona te u kaznenoj sferi i dalje ostaju kažnjivi svi ostali, teži modaliteti (preprodaja, organiziranje preprodaje, neovlašteni uzgoj i proizvodnja, omogućavanje uporabe drugoj osobi, davanje djetetu).

43 Turković et al., op. cit. (bilj. 13), str. 237.

44 Županijski sud u Bjelovaru, Kž-182/2016, 17. studenoga 2016. Sud je našao irelevantnim što je okrivljenik držao drogu isključivo radi prerade za osobnu uporabu jer je nedvojbeno bio svjestan da uporaba lijekova koji sadrže THC za liječenje dijabetesa nije legalna i da je namjeravao preraditi tvari koji su propisom proglašene drogom, iako je to za njega zabranjeno.

Vrhovni sud Republike Hrvatske, I Kž 60/12-7, 27. studenoga 2014.

46 Vidjeti KZ/11, čl. 190. st. 3. te 191. st. 2. Također, zapriječene su kazne snižene za gotovo ve oblike (ili posebni minimum ili posebni maksimum ili oboje). Tako, primjerice, kazna za onoga tko proizvodi, prerađuje, prodaje ili nudi na prodaju ili posreduje u prodaji ili kupnji sada je od 1 godine do 12 godina, dok je izmjenom KZ-a/97 (2006. godine) ona glasila najmanje tri godine zatvora. Nekada visoke kazne zatvora za samo posjedovanje droge prerasle su u prekršajne novčane kazne pa u svakom slučaju možemo govoriti u trendu opće liberalizacije u području zlouporabe droga. 
stupio na snagu. Nadalje, proučavajući podatke DZS-a u sferi navedenih djela, proizlazi kako se najviše kaznenih djela odnosi na stavke 1. i 2. čl. 190., odnosno st. 1. i 2. čl. 173. ${ }^{47}$

\begin{tabular}{|l|c|c|c|c|c|c|c|c|}
\hline Godina & 2010. & 2011. & 2012. & 2013. & 2014. & 2015. & 2016. & 2017. \\
\hline Optužene osobe & 2.726 & 2.839 & 1.949 & 775 & 851 & 625 & 666 & 640 \\
\hline Osuđene osobe & 2.394 & 2.472 & 1.747 & 702 & 770 & 570 & 618 & 590 \\
\hline
\end{tabular}

Tablica 1: Optužene i osuđene punoljetne osobe za kazneno djelo Zlouporabe droga odnosno Neovlaštena proizvodnja i promet drogama (čl. 173. / čl. 190.) ${ }^{48}$

\subsection{PREKRŠAJNOPRAVNA REAKCIJA}

Sukladno čl. 1. Prekršajnog zakona, prekršaji i prekršajno-pravne sankcije propisuju samo za ona ponašanja kojima se povređuje ili ugrožava javni poredak, društvena disciplina i društvene vrijednosti zajamčene i zaštićene Ustavom Republike Hrvatske, međunarodnim pravom i zakonima čija zaštita nije moguća bez prekršajnopravnog sankcioniranja, a njihova zaštita se ne ostvaruje kaznenopravnom prisilom. Zakon o suzbijanju zlouporabe droga ${ }^{49}$ koji regulira temeljna pitanja ove materije, usvojen je 2001. godine te je u međuvremenu mijenjan nekoliko puta. Sukladno čl. 2. st. 1. t. 1., droga jest svaka tvar prirodnoga ili umjetnoga podrijetla, uključivši psihotropne tvari, uvrštene u popis droga i psihotropnih tvari. ${ }^{50}$ Ukupno deset članaka u Glavi X. (čl. 54. do 64.) propisuje prekršajno sankcioniranje. Predmet ovog rada usmjeren je na prekršaj iz čl. 54. st. 1. t. 1. (uz st. 3. koji propisuje sankciju), odnosno protupravno posjedovanje droge, biljki ili dijelova biljke iz kojih se može dobiti droga i nove psihoaktivne tvari ili pak tvari koje se mogu uporabiti za izradu droge i nove psihoaktivne tvari, a propisana je novčana kazna u rasponu od 5.000,00 do 20.000,00 kuna ili novčana kazna od 90 dana. ${ }^{51}$

Uz novčanu kaznu, sukladno čl. 64. ZOSZD-a, propisano je oduzimanje sredstava za izradu droge te izricanje zaštitnih mjera zabrane obavljanja djelatnosti (od tri mjeseca do jedne go-

47 Pogledati podatke vezane uz brojčane pokazatelje kaznenih djela publikacije Punoljetni počinitelji kaznenih djela - prijave, optužbe i osude u 2010., 2011., 2012., 2013., 2014., 2015., 2016., 2017. godini, Državni zavod za statistiku, URL= http:// digured.srce.hr/webpac-hidra-pprh/?rm=results\&show-full=1\&f=IDbib\&v=SD010332. Pristupljeno 12. rujna 2018.

48 Podaci za izradu tablice preuzeti su iz online publikacije: Punoljetni počinitelji kaznenih djela - prijave, optužbe i osude u 2010., 2011., 2012., 2013., 2014., 2015., 2016., 2017. godini, Državni zavod za statistiku, http://digured.srce.hr/webpac-hidra$\mathrm{pprh} /$ ?rm=results\&show-full=1\&f=IDbib\&v=SD010332. Pristupljeno 12. rujna 2018.

49 Zakon o suzbijanju zlouporabe opojnih droga, Narodne novine, broj 107/2001, 87/2002, 163/2003, 141/2004, 40/2007, 149/2009, 84/2011, 80/2013, 39/2019. dalje ZOSZD.

50 Zakon uređuje nadzor nad uzgojem biljaka iz kojih se mogu dobiti droge te nadzor nad izradom, posjedovanjem i prometom droga kao i mjere za suzbijanje zlouporabe droga te sustav za prevenciju ovisnosti i pomoć ovisnicima i povremenim uzimateljima droga, a propisane su i evidencije o uzgoju biljaka iz kojih se može dobiti droga i njihovoj izradi, vrsti i količini, držanju, preradi, prodaji ili stavljanju u promet ili bilo kojem drugom raspolaganju.

51 Sukladno čl. 54. st. 1.-3. ZOSZD-a prekršajno-pravna odgovornost i isti raspon kazne predviđen je još za sljedeće radnje: promicanje izrade, posjedovanja, uporabe ili prometa drogom ili novim psihoaktivnim tvarima te oglašavanje, uzgoj maka za izradu droge izvan propisanih uvjeta ili uz nepoštovanje odobrenih uvjeta, odnosno ne obavještavanje policijske postaje o sumnji na izradu droge, kršenje odredbi o čuvanju, uzgoju i predaji, prijavi i uništavanju maka te za uzgoj za znanstvene svrhe ili bez odobrenja. Treba istaknuti kako se najznačajnija novost posljednjih izmjena (stupile na snagu 25. travnja 2019.) odnosi na uvrštavanje novih psihoaktivnih tvari u regulaciju kao i uvođenje zatvorske kazne od 90 dana kao alternativne. 
dine) i zabrane obavljanja djelatnosti pravnoj osobi u istom trajanju ako je prekršaj počinjen u obavljanju te djelatnosti pri čemu je osobito važno da preduvjeti izricanja zaštitnih mjera moraju biti obrazloženi. ${ }^{52}$ Počinitelju, ovisniku ili povremenom konzumentu, može se izreći zaštitna mjera obveznog liječenja u zdravstvenoj ustanovi ili zaštitna mjera liječenja od ovisnosti u ustanovi socijalne skrbi, udruzi odnosno drugoj pravnoj osobi u trajanju od tri mjeseca do godine dana pri čemu se okolnost ovisništva ili povremenog uzimanja također mora obrazložiti. ${ }^{53}$ Ako je prekršaj počinjen prvi put, a riječ je o počinitelju ovisniku ili povremenom uzimatelju droge, tad se zaštitna mjera može izreći samostalno. ${ }^{54}$

Posjedovanje je određeno kao faktična vlast nad opojnom drogom, biljkom ili tvari koja se može uporabiti za izradu opojne droge. ${ }^{55}$ Količina posjedovane droge unutar prekršajnopravne sfere nije postavljena zakonskom odredbom, pa se time otvara pitanje gornje granice posjedovane količine i potencijalna aktivacija mehanizma kaznene naravi. Zakonodavac je ostavio odgovor prosudbi sudske prakse in concreto. Iz Ministarstva pravosuđa svojevremeno je objašnjeno da je prihvaćeno rješenje rezultat ne samo komparacije drugih sustava nego i praktičnih razloga - mogućim negativnim posljedicama fiksno postavljenih granica - propisana bi količina ujedno predstavljala mogućnost zlouporabe od strane preprodavača (imati uz sebe tek neznatno niže količine od potencijalno propisanih koje bi ulazile u modalitet posjedovanja za osobnu uporabu i time izbjeći kazneni progon). ${ }^{56}$

Postoje i slučajevi u kojima posjedovanje droge nije kažnjivo. Ovlašteno posjedovanje droge (odobrenjem nadležnog ministra zdravstva) predviđeno je osobama koje obavljaju nastavu i stručnu izobrazbu, analizu i dresuru životinja za otkrivanje droga. Dodatno, za svrhe simuliranog otkupa i nadzirane isporuke službena osobe policije pod propisanim uvjetima radi otkrivanja kaznenog djela i počinitelja. Drogu mogu posjedovati i zdravstvene i veterinarske ustanove, doktori medicine i stomatologije, punoljetni bolesnici kao i roditelji, odnosno skrbnici maloljetnih bolesnika, doktori veterinarske medicine te zapovjednici brodova i zrakoplova, djelatnici koji provode prevencijske programe te znanstvenoistraživačke projekte. ${ }^{57} \mathrm{U}$ sferi

52 Rješenjem Visokog prekršajnog suda preinačena je presuda i ukinuta izrečena zaštitna mjera jer prvostupanjski sud nije, u skladu s člankom 53. stavkom 1. Prekršajnog zakona, utvrdio da je okrivljenik predmetni prekršaj počinio pod odlučujućim djelovanjem ovisnosti o drogi, odnosno da postoji opasnost da će zbog te ovisnosti u budućnosti počiniti prekršaj, a što su odlučne činjenice za izricanje zaštitne mjere obveznog liječenja od ovisnosti o drogi. Rješenje Jž - 2490/14, 31. ožujka 2015.

Visoki prekršajni sud je rješenjem ukinuo prethodnu presudu i vratio predmet na ponovno suđenje kada prvostupanjski sud navodi da je okrivljenica predmetnu drogu posjedovala za osobnu uporabu, iako je ista u svojoj obrani jasno navela da ne konzumira nikakve droge te je predmetnu drogu evidentno nabavila radi budućeg, eventualnog konzumiranja. Ne utvrđivanje odlučnih činjenica za primjenu predmetne zaštitne mjere - činjenica okrivljeničine ovisnosti ili povremene konzumacije iste, čini primjenu ove mjeru neosnovanom. Rješenje Visokog prekršajnog suda Jž-3608/2012, 10. travnja 2014.

54 U tom smislu, Visoki je prekršajni sud donio rješenje kojim ukida presudu i predmet vraća na ponovnu odluku kad Prekršajni sud nije pravilno utvrdio da je riječ o takvoj situaciji. Naime, na temelju uvida u prekršajnu evidenciju jednog suda, u ovom slučaju prvostupanjskog suda, ne može se utvrditi prekršajna kažnjavanost pojedinog okrivljenika već je o istom potrebno pribaviti podatke od Ministarstva pravosuđa. Rješenje Visokog prekršajnog suda broj Jž-4411/2013, 9. travnja 2014.

55 Članak 2. st. 1. t. 9. ZOSZD-a. Ovaj je modalitet imao različite regulativne varijacije - neovlašteno posjedovanje bilo je prije 1997. godine u kaznenoj sferi samo ako je bilo namijenjeno za proizvodnju, u razdoblju od 1997. do 2002. za svako se posjedovanje kazneno odgovaralo, a 2003. postalo samostalna radnja i to ponovno samo u slučaju prodaje ili drugog načina stavljanja u promet.

56 Detaljnije, Posjedovanje droge za osobnu uporabu prekršajno, a ne kazneno djelo, URL=https://pravosudje.gov.hr/posjedovanjedroge-za-osobnu-uporabu-prekrsajno-a-ne-kazneno-djelo/6388. Pristupljeno 13. srpnja 2018. S druge strane, negativni je vid ovog rješenja iskazana bojazan policijske službe kako će konzumenti teže priznavati od koga su nabavili drogu, jer znaju da posjedovanjem čine samo prekršaj. 
prekršajnog zakonodavstva postoje i drugi zakoni koji propisuju kažnjiva ponašanja vezana uz zlouporabu droga. Primjerice, Zakon o prekršajima protiv javnog reda i mira zabranjuje opijanje ili uživanje droga / omamljujućih sredstava na javnom mjestu. ${ }^{58}$ Zakon o sprječavanju nereda na športskim natjecanjima zabranjuje posjedovanje ili konzumiranje droga kao i pokušaj unošenja ili unošenje droga u športski objekt. ${ }^{59}$ Zakon o sigurnosti prometa na cestama zabranjuje upravljanje ili početak upravljanja vozilom na cesti pod utjecajem droga, kao i davanje vozila na upravljanje osobi pod utjecajem droga. ${ }^{60}$ Zakon o provedbi uredbi Europske unije iz područja prekursora za droge predviđa prekršajno sankcioniranje za pravne osobe ali i fizičke osobe u pravnim osobama za radnje vezane uz prekursore za droge. ${ }^{61}$

\section{UVID U OBILJEŽJA PREKRŠAJNOPRAVNE JUDIKATURE SUDA U BJELOVARU}

U ovom dijelu analiziramo prekršajnu praksu na manjem uzorku pravomoćnih presuda. Riječ je o uvidu u nasumično odabranu sudsku praksu koji ne pretendira biti podloga za opće zaključke o sudskim stavovima. Nakon uvida u dvadeset i dvije prekršajne presude ${ }^{62}$ te jednog rješenja o sudskom ukoru prema maloljetniku ${ }^{63}$ suda u Bjelovaru, rezultati pokazuju kako se kod ovog prekršaja vezano uz vrstu droge u najvećem broju slučajeva radi upravo o marihuani. Najvažnije su spoznaje dobivene istraživanjem uvrštene u Tablicu 2 (niže u tekstu) u kojoj su razmatrane presude prema podacima vezanima uz količinu i vrstu posjedovane droge, dob i stručnu spremu osuđene osobe te izrečenu sankciju.

58 Članak 20., Zakon o prekršajima protiv javnog reda i mira, Narodne novine, broj 5/1990, 30/1990, 47/1990, 29/1994. Mora biti riječ o ponavljanju radnji uživanja droga na javnom mjestu. Vidjeti i Nikšić, Siniša, op. cit. u bilj. 4, str. 631.

59 Članak 39. st. 1., Zakon o sprječavanju nereda na športskim natjecanjima, Narodne novine, broj 117/2003, 71/2006, 43/2009, $34 / 2011$.

60 Zakon o sigurnosti prometa na cestama, Narodne novine, broj 67/2008, 48/2010, 74/2011, 80/2013, 158/2013, 92/2014, 64/2015, 108/2017, članci 181., 199., 221., 229., 231., 282. i 285. Podaci iz 2014. godine govore da je u nadzoru prometa testirano 794 vozača na prisutnost droga, a kod njih 230 utvrđena je prisutnost droga. Prekršajno je procesuirano 396 vozača, od toga broja 218 zbog odbijanja podvrgavanja testiranju, 117 zbog odbijanja davanja uzoraka krvi i urina te 61 zbog utvrđene prisutnosti opojnih droga na temelju provedene analize krvi i urina. Nacionalni program - Suzbijanje zlouporabe droga, Ministarstvo unutarnjih poslova Republike Hrvatske, URL=https://www.mup.hr/ public/documents/Nacionalni\%.20programi/ Nacionalni\%20program\%20-\%20Suzbi janje\%20zlouporabe \%20droga.pdf. Pristupljeno 14. srpnja 2018., str. 5.

61 Zakon o provedbi uredbi Europske unije iz područja prekursora za droge, Narodne novine, broj 80/2013, čl. 13.

62 Presude Pp J- 830/17-19 od 22. prosinca 2017., Pp J-22/17-44 od 13. travnja 2017., Pp J-631/17-17 od 7. prosinca 2017., Pp J-498/17-12 od 31. kolovoza 2017., Pp J-91/17 od 21. rujna 2017., Pp J-496/17-12 od 3. studenog 2017., Pp J-217/18-12 od 28. svibnja 2018., Pp J-805/17-18 od 18. siječnja 2018., Pp J-428/17-10 od 8. lipnja 2017., Pp J-183/16-10 od 15. ožujka 2016., Pp J-324/17-24 od 3. srpnja 2017., Pp J-134/18-10 od 7. lipnja 2018., Pp J-922/17-9 od 27. ožujka 2018., Pp J-232/18-11 od 14. lipnja 2018., Pp J-897/16-9 od 7. prosinca 2016., Pp J-833/16-8 od 3. veljače 2017., Pp J-271/15-20 od 10. studenog 2015. , Pp J-438/15-8 od 16. ožujka 2016., Pp J-46/18-9 od 8. svibnja 2018., Pp J-368/16-11 od 7. lipnja 2016., Pp J-875/17-13 od 8. studenog 2017., Pp J-610/17-10 od 25. srpnja 2017. 


\begin{tabular}{|c|c|c|c|c|}
\hline $\begin{array}{l}\text { Količina droge u } \\
\text { posjedu }\end{array}$ & Vrsta droge & \begin{tabular}{|l|} 
Dob \\
osudenika \\
\end{tabular} & $\begin{array}{l}\text { Stručna sprema } \\
\text { osuđenika }\end{array}$ & Izrečena kazna \\
\hline $\begin{array}{l}\text { neutvrđena } \\
\text { (tragovi u drobilici) }\end{array}$ & marihuana & 27 & SSS & $\begin{array}{l}\text { Zaštitna mjera do } \\
\text { uspješnosti liječenja, } \\
\text { najduže } 12 \text { mjeseci }\end{array}$ \\
\hline $0,09 \mathrm{~g}$ & marihuana & 23 & SSS & $1.500 \mathrm{HRK}$ \\
\hline $0,3 \mathrm{~g}$ & marihuana & 40 & NSS & $1.000 \mathrm{HRK}$ \\
\hline $0,4 \mathrm{~g}$ & marihuana & 19 & SSS & $5.000 \mathrm{HRK}$ \\
\hline $0,5 \mathrm{~g}$ & marihuana & 18 & učenik & $\begin{array}{l}\text { Zaštitna mjera u } \\
\text { trajanju } 6 \text { mj. }\end{array}$ \\
\hline $0,7 \mathrm{~g}$ & marihuana & 20 & SSS & 5.000 HRK \\
\hline $0,8 \mathrm{~g}$ & marihuana & 19 & učenik & 1.500 HRK \\
\hline $0,14 \mathrm{~g}$ & marihuana & 19 & SSS & $\begin{array}{l}4.000 \text { HRK + zaštit- } \\
\text { na mjera }(3-6 \text { mj. })\end{array}$ \\
\hline $0,33 \mathrm{~g}$ & marihuana & 23 & SSS & $1.500 \mathrm{HRK}$ \\
\hline $0,73 \mathrm{~g}$ & marihuana & 29 & NSS & $\begin{array}{l}\text { 5.100 HRK + zaštit- } \\
\text { na mjera od } 1 \text { god. }\end{array}$ \\
\hline $0,73 \mathrm{~g}$ & marihuana & 18 & učenik & Zaštitna mjera 6 mj. \\
\hline $1,6 \mathrm{~g}$ & marihuana & 22 & SSS & $1.500 \mathrm{HRK}$ \\
\hline $1,8 \mathrm{~g}$ & marihuana & 27 & nepoznato & Zaštitna mjera 6 mj. \\
\hline $3 \mathrm{~g}$ & marihuana & 31 & SSS & $3.000 \mathrm{HRK}$ \\
\hline 1 joint & marihuana & 25 & SSS & Zaštitna mjera 6 mj. \\
\hline 1 joint & marihuana & 33 & VSS & Zaštitna mjera $6 \mathrm{mj}$. \\
\hline 1 joint & marihuana & 25 & student & Zaštitna mjera 6 mj. \\
\hline 1 joint & marihuana & 19 & NSS & 675 HRK \\
\hline 1 joint & marihuana & 21 & nepoznato & $5.000 \mathrm{HRK}$ \\
\hline $28,9 g+0,9 g$ & $\begin{array}{l}\text { Speed }+ \\
\text { marihuana }\end{array}$ & 30 & SSS & $\begin{array}{l}\text { 5.100 HRK + zaštitna } \\
\text { mjera od } 1 \text { god. }\end{array}$ \\
\hline $1,5 g+52,5 g$ & $\begin{array}{l}\text { Kokain }+ \\
\text { marihuana }\end{array}$ & 38 & SSS & $3.000 \mathrm{HRK}$ \\
\hline 27 komada tableta & Normabel & 28 & NSS & 3.000 HRK \\
\hline
\end{tabular}

Tablica 2: Presude Suda u Bjelovaru za prekršajna djelo iz čl. 54. st. 1. ZOSZD-a

Prethodno je objašnjen izostanak striktnih raspona glede količine droge kao i izostanak specifikacije droge u predmetnoj odredbi ZOSZD-a, a kad je riječ o prikladnom prekršajno-pravnom sankcioniranju, može se načelno reći kako je riječ o onoj drogi koja nije namijenjena za preprodaju, za stjecanje nekakve imovinske koristi i koja se koristi u manjoj količini.

Vezano uz količine, proučeni slučajevi pokazuju kako je raspon posjedovane količine zaista različit. Najveća je količina droge uočena u istraženim presudama 52,5 grama marihuane uz 
1,5 gram kokaina, ${ }^{64}$ a najmanja količina je neutvrđene težine, odnosno riječ je o postojanju tragova biljne materije. ${ }^{65} \mathrm{U}$ većini slučajeva radi se o jednom tzv. jointu ili o količini manjoj od jednog grama. Utoliko se zaključuje kako, barem zasad, nema specifičnih striktnih ograničenja u pogledu maksimalne količine te se prekršajno-pravna reakcija ravna prema in concreto okolnostima koje ukazuju na isključivo osobnu uporabu, odnosno nedostatak onih okolnosti koje su ostavljene u kaznenopravnoj sferi (proizvodnja, prodaja i sl.). ${ }^{66} \mathrm{U}$ pogledu vrste droge, najznačajniji je zaključak kako pojava i "težih" droga nije zapreka za prekršajno-pravnu reakciju. Proučeni slučajevi ukazali su da je najčešće riječ o tzv. lakoj drogi, odnosno marihuani. Ipak, značajna je spoznaja da istovremeno posjedovanje različitih vrsta droge, tzv. "lake" i "teške", nije zapreka prekršajnopravnom mehanizmu (posjedovanje marihuane, i to u najvećoj količini od proučenih slučajeva, te kokaina).

U pogledu socioekonomskih obilježja počinitelja, riječ je mahom o osobama muškog spola, što je i u skladu s prethodno spomenutim istraživanjima. ${ }^{67}$ Raspon dobi kreće se od 18 do 40 godina života, s time da je najčešća dob 19 godina (18\%). U pogledu stručne spreme, najčešće je riječ o srednjoj stručnoj spremi (50\%), potom slijedi niža stručna sprema (18\%). Dvije osobe nemaju utvrđenu stručnu spremu, a među osuđenim osobama tri su učenika, jedan student te jedna osoba s visokom stručnom spremom.

Politika je kažnjavanja u proučenim slučajevima bila načelno blaga. Bez obzira na visoku zapriječenu novčanu kaznu, izrečene se kazne kreću ispod ili oko minimuma smatrajući kako se i takvom sankcijom ostvaruje svrha kažnjavanja. Naime, unatoč visokoj propisanoj novčanoj kazni od pet do dvadeset tisuća kuna, zanimljivo je istaknuti kako je u znatnom broju slučajeva izrečena sankcija ispod minimuma ili tek minimum (primjerice, u više od polovice ukupnih promatranih slučajeva, koji su zapravo svi gdje je novčana kazna uopće izrečena, dakle njih petnaest, novčana se kazna kreće u rasponu od 675,00 do 5.100,00 HRK).

Vidljiva je česta uporaba mogućnosti izricanja iznosa manjeg od zakonskog minimuma, ${ }^{68}$ što se obrazlaže različitim okolnostima: priznanjem krivnje (kod svih promatranih slučajeva), prethodnom neosuđivanošću, kajanjem, obiteljskim stanjem (koje se često ne obrazlaže pa nije vidljivo zbog kojih razloga u konkretnom slučaju utječe na visinu izrečene sankcije), imovinskim stanjem (nezaposlenost, obveza uzdržavanja), uspješno školovanje bez devijacije, otklanjanjem uzroka prekršaja liječenjem. Od otegotnih okolnosti čest je recidivizam ili rjeđe,

64 Okrivljenik je, kako tvrdi, na poslovnom putu u Beogradu kupio navedenu količinu droge te dovezao u Hrvatsku pri povratku. U večeri kada je uhićen, nalazio se u kafiću s društvom gdje je bio pod većim utjecajem alkohola, a sa sobom je ponio i drogu. Napominje da je marihuanu i kokain imao isključivo za vlastite potrebe, koje je kupio iz znatiželje i nije imao namjeru prodavati ili ikoga častiti drogom. U ovoj presudi sud uzima kao olakotne okolnosti priznanje djela te kajanje okrivljenika, kao i to da nije već prekršajno kažnjavan zbog ovog djela te zbog činjenice da je otac maloljetnog djeteta s vrlo malim primanjima. Kao otegotnu okolnost sud uzima posjedovanje veće količine opojne droge te izriče novčanu kaznu od 3.000 kuna. Pp J-631/17-17, Prekršajni sud u Bjelovaru, od 7. prosinca 2017.

65 Okrivljenik je posjedovao metalnu drobilicu u kojoj su zaostali tragovi zelene biljne materije točno neutvrđene težine, koja je u Centru za forenzična ispitivanja prepoznata kao Canabis marihuana. Pp J-22/17-44, Prekršajni sud u Bjelovaru, 13. travnja 2017.

66 Radi utvrđivanja namjere prodaje, Kozary navodi optuženikov iskaz, odnosno priznanje kao primaran dokaz. No, ako priznanje izostaje, okolnost da je droga namijenjena prodaji i ocjena namjere može se izvesti iz drugih okolnosti koje prate djelo. Primjerice, količina pronađene droge, način na koji je zapakirana, tvari ili sredstva koja se koriste za miješanje $s$ drogom pri prodaji, priprema jednokratnih doza, okolnosti pod kojima je počinitelj zatečen... Kozary, op. cit. (bilj. 40), str. 108.

67 Dodatno vidjeti i rezultate koje su istraživanjima na ovom području dobili i drugi autori. Primjerice, cf. ibid., str. 120.-123. te Garačić, A., Zakonska i sudska politika kažnjavanja županijskih sudova u RH za kaznena djela silovanja i zloporabe droga, Hrvatski ljetopis za kazneno pravo i praksu, Zagreb, god. 11, br. 2, 2004., str. 475.-516. 
zatečena veća količina droge. U sedam slučajeva, gotovo $32 \%$, sukladno zakonskom rješenju izrečene su isključivo zaštitne mjere obveznog liječenja ili odvikavanja od ovisnosti od droga, najčešće u trajanju od 6 mjeseci. Riječ je o okrivljenicima kojima se prvi put sudi za ovaj prekršaj, najčešće povremenim konzumentima kod kojih se još nije mogla razviti znatna navika i posebna ovisnost, a smatra se da se samom mjerom može postići svrha kažnjavanja u smislu specijalne prevencije. Također, među presudama se mogu naći i one kojima se izriče novčana kazna uz zaštitnu mjeru obveznog liječenja ili odvikavanja od ovisnosti kod recidivista ovog prekršaja, ovisnicima ili povremenim uzimateljima droge. U potonjim su slučajevima izricane novčane kazne u višim iznosima, a zaštitna mjera se uglavnom određuje na godinu dana.

Prije zaključnih misli treba istaknuti kako se trend liberalizacije u području konzumiranja droge nastavio i nakon prikazanih legislativnih izmjena. Naime, od sredine listopada 2015. godine usvojenim izmjenama i dopunama Pravilnika o mjerilima za razvrstavanje lijekova te o propisivanju i izdavanju lijekova na recept ${ }^{69}$ omogućena je uporaba kanabisa za medicinske svrhe. Oboljeli od multiple skleroze, karcinoma, epilepsije i AIDS-a, za ublažavanje tegoba mogu na recept dobiti lijekove koji sadrže THC, dronabilon i nabilon. Međutim, liječnici moraju receptom propisati količinu THC-a za pojedinačnu dozu, vrstu biljne droge i biljnog pripravka, broj doza te oblik. Takvo liječenje može trajati najviše 30 dana, a količina marihuane ne može biti veća od 7,5 grama. Nova su kretanja izazvala dosta zanimanja te je predmetna regulacija ubrzo bila podnesena na odluku Ustavnom sudu radi ocjene suglasnosti s Ustavom i zakonom. ${ }^{70}$

\section{ZAKLJUČNE MISLI}

Područje istraživanja ovog rada jesu legislativni i praktični aspekti posjedovanja droge kao prekršajnog djela u Republici Hrvatskoj. S tim u vezi u središte se rada stavlja, pored provedenog istraživanja, upravo prikaz zakonodavnog kontinuiteta i promjena kroz godine radi prikaza pomaka i promjena u shvaćanju i rješavanju problema zlouporabe droga. Evolucija društvenih i legislativnih pozicija i značajan iskorak pomicanja fokusa s kaznenopravnih na prekršajnopravne odredbe ujedno otvara i mnoga pitanja. U ovom kontekstu, s obzirom na prihvaćeni izričaj predmetne odredbe, ona se primarno referiraju na početno postavljena istraživačka pitanja - vrstu te količinu droge koja se pojavila u istraženim presudama. Treba istaknuti kako je riječ o uvidu u manji broj sudskih presuda koji ne služi kao slika općih sudskih stajališta (za to bi bilo potrebno provesti istraživanje mnogo značajnijih razmjera) no svakako je zanimljiv kao uzorak i podloga u kontekstu dodatnih saznanja fenomenologije odabranog prekršaja, socioekonomskih obilježja počinitelja te u konačnici primijenjene sudske politike kažnjavanja. U nastavku se zaključnih misli daju odgovori na postavljena pitanja koji pokazuju

69 Članak 30.a i 30.b, Pravilnik o izmjenama i dopunama Pravilnika o mjerilima za razvrstavanje lijekova te o propisivanju i izdavanju lijekova na recept, Narodne novine, broj 107/2015. Narodne novine, broj 86/2013, 90/2013, 102/2014, 107/2015, $72 / 2016$.

70 Naime, podnositelj je prigovarao što na listu navedenih bolesti iz čl. 30.a navedenog Pravilnika nisu stavljene i osobe koje boluju od neuropatske boli kako bi se i njima mogli propisivati lijekovi koji sadrže medicinski kanabis. Međutim, Ustavni je sud rješenjem odbacio podneseni prijedlog smatrajući kako nije nadležan odlučivati o prijedlogu jer predlagatelj nije naveo ustavnopravno relevantne razloge zbog kojih bi trebalo provesti ocjenu suglasnosti, a pojedinu odredbu neustavnom i suprotnom zakonu samo zato što nešto nije uređeno ili nije uređeno na način koji predlagatelj smatra ispravnim. U-II/4038/2015, 11. srpnja 2017. 
kako su neke predstavljene početne istraživačke pretpostavke potvrđene, a neke nisu. Istraživanje je pokazalo dominantnu prevalenciju marihuane kao lakšeg tipa droga, ali se pojavila i kombinacija posjedovanja s drugim (težim) vrstama droge. Vrlo je zanimljivo istaknuti da je došlo do spoznaje kako vrsta posjedovane droge nije odlučna prilikom prekršajnog sankcioniranja jer u obzir dolaze i "teže” droge (kokain, speed/amfetamini) ako je količina takva da ne ukazuje na neke modalitete koji su ostali pod kaznenopravnim mehanizmom. Iako to nije u suprotnosti s pozitivnom predmetnom odredbom, vrijedi kao poticaj razmišljanju zavređuju li konzumenti takvih droga jednak tretman poput onih koji su konzumenti isključivo lakših oblika droga, i to poglavito ako posjeduju više vrsta droge. Isto tako, količina posjedovane droge u ispitanim je slučajevima varirala, i to bez mogućnosti uspostave nekog standardnog raspona. Iako je u većini slučajeva riječ o manjim količinama, ispod ili nešto iznad jednog grama, bilo je i slučajeva koji su uključivali količine preko dvadeset ili pedeset grama. Nadalje, istraživanje je potvrdilo pretpostavku da je riječ o "muškom" deliktu, što je sukladno i ranijim spoznajama u predmetnom području, i to prevalentno mlade dobi u što su uključeni i učenici i studenti. Dodatno, riječ je o pojedinačnom deliktu koji se čini bez sudioničkih uloga u djelu. U pogledu kažnjavanja, istraživanje naglašava principijelnu blagonaklonost sudaca u pogledu sankcioniranja: izrečene su novčane kazne općenito niske i blage u odnosu na raspon koji je predvidio zakonodavac. Naime, promatrajući iskorištenost omogućenih okvira kažnjavanja, evidentno je da je najviša izrečena kazna zapravo zakonski minimum, pri čemu u značajnom broju slučajeva prevladava ispodminimumska kazna. Utoliko ne preostaje drugo nego zaključiti kako se omogućeni rasponi novčane kazne u praksi uopće ne koriste. To dalje ukazuje na različite pozicije legislative i judikature - propisujući okvir novčane kazne od pet do dvadeset tisuća kuna zakonodavac je imao na umu društvenu štetnost i neprihvatljivost ovoga ponašanja. S druge strane, učinkovit utjecaj na promjenu prikazane prakse sankcioniranja neće imati možebitno povećanje propisanog maksimuma. Promjene bi primjerice mogle biti učinjene eventualnom intervencijom u odredbe o ublažavanju kazne za koje je istraživanje pokazalo kako se učestalo koriste. Konačno, zatvorska kazna od 90 dana uvedena je recentnim izmjenama te promatrani slučajevi nisu njome obuhvaćeni. Kao takva, pokazuje represivniji stav zakonodavca prema kažnjavanju, no tek treba vidjeti hoće li se i na koji način afirmirati u sudskoj praksi. Općenito govoreći, svrha se legislativnih promjena, poglavito s obzirom na proklamirane razloge tih promjena, u području posjedovanja droge bez namjere stavljanja u promet, može smatrati uspjelom i pozitivnom. S obzirom na prikazani način recepcije ovih promjena u judikaturi, ovo istraživanje, s obzirom na insuficijentnost proučavanja, treba poslužiti kao poticaj daljnjem izučavanju praktičnih učinaka usvojenog rješenja, primarno kad je riječ o sankcioniranju. 


\section{LITERATURA}

\section{ČLANCI, MONOGRAFIJE, PUBLIKACIJE:}

1. Bonačić, M.; Tomašić, T., Implementacija standarda Europskog suda za ljudska prava u hrvatskom prekršajnom pravu i praksi, Hrvatski ljetopis za kaznene znanosti i praksu, Zagreb, god. 24, br. 2, 2017., str. 381.-411.

2. Bonačić, M.; Rašo, M., Obilježja prekršajnog prava i sudovanja, aktualna pitanja i prioriteti de lege ferenda, Hrvatski ljetopis za kazneno pravo i praksu, Zagreb, god. 19, br. 2, 2012., 439.-472.

3. Cvitanović, L.; Rogić-Haždalić, D.; Mrčela, M., Zlouporaba opojnih droga 1998.-2007., Studije i analize 107, Državni zavod za statistiku, Zagreb, 2010.

4. Cvjetko, B., Kazneno zakonodavstvo i kaznenopravna reakcija na kazneno djelo zlouporabe opojnih droga u Republici Hrvatskoj, Hrvatski ljetopis za kazneno pravo i praksu, Zagreb, god. 10, br. 2, 2003. 909.-939.

5. Derenčinović, D.; Gulišija, M.; Dragičević Prtenjača, M., Novosti u materijalnopravnim odredbama Prekršajnog zakona, Hrvatski ljetopis za kazneno pravo i praksu, god. 20, br. 2, 2013., str. 751.-777.

6. Drogen- und Suchtbericht, Die Drogenbeauftragte der Bundesregierung, Bundesministerium für Gesundheit, Berlin, 2015.

7. Državni zavod za statistiku, Počinitelji prekršaja u 2017., Statistička izvješća 1629, Zagreb, 2018.

8. Dubreta, N., Društvo i odnos prema drogama: sociokulturni kontekst upotrebe kanabisa, Hrvatska sveučilišna naklada: Pučko otvoreno učilište, Zagreb, 2005.

9. Europsko izvješće o drogama - trendovi i razvoj, Luksemburg, Ured za publikacije Europske unije, 2019.

10. Garačić, A., Zakonska i sudska politika kažnjavanja županijskih sudova u RH za kaznena djela silovanja i zloporabe droga, Hrvatski ljetopis za kazneno pravo i praksu, god. 11, br. 2, 2004. 475.-516.

11. Hoffman, A., Drogenkonsum und - kontrolle, Zur Etablierung eines soziales Problems im ersten Drittel des 20. Jahrhunderts, Springer Fachmedien Wiesbaden, 2012.

12. Ivičević Karas, E., Načelo ne bis in idem u europskom kaznenom pravu, Hrvatski ljetopis za kazneno pravo i praksu, Zagreb, god. 21, br. 2, 2014., 271.-294.

13. Ivičević Karas, E.; Kos, D., Primjena načela ne bis in idem u hrvatskom kaznenom pravu, Hrvatski ljetopis za kazneno pravo i praksu, god. 19, br. 2, 2012., str. 555.-584.

14. Jescheck, H.-H; Weigend, T., Lehrbuch des Strafrechts, Allgemeiner Teil, Berlin, 1996,

15. Josipović, I., Novi prekršajni zakon: konačno, reformski iskorak, u: Ivo Josipović, Marko Rašo, Prekršajni zakon, Narodne novine, 2008.

16. Josipović, I.; Novak Hrgović, K., Načelo ne bis in idem u kontekstu prekršajnog, kaznenog i upravnog prava, Hrvatski ljetopis za kaznene znanosti i praksu, god. 23, br. 2, 2016., str. 469.-507.

17. Jurlina Alibegović, D.; Slijepčević, S., Procjena javnih rashoda u području suzbijanja zlouporabe droga u Hrvatskoj, Društvena istraživanja: časopis za opća društvena pitanja, god. 24, br. 1, 2015., 1.-20.

18. Klarić, D., Droga i kriminal: važni metodički pristupi suzbijanja, Udruga "Znanje daje sigurnost", Zagreb, 2008.

19. Kozary, D., Zlouporaba opojnih droga, Pravni vjesnik, god. 27, br. 1, 2011., 101.-126.

20. Nikšić, S., Prekršajna djela zlouporabe droga i učinci nakon dekriminalizacije kaznenog djela posjedovanja droge bez namjere njezina stavljanja u promet te osvrt na neke aspekte Prekršajnog zakona, Hrvatski 
ljetopis za kazneno pravo i praksu, Zagreb, god. 21, br. 2, 2014., 619.-641

21. Novosel, D.; Rašo, M.; Burić, Z., Razgraničenje kaznenih djela i prekršaja u svjetlu presude Europskog suda za ljudska prava u predmetu Maresti protiv Hrvatske, Hrvatski ljetopis za kazneno pravo i praksu, vol. 17, br. 2, 2010., str. 785.-812.

22. Novoselec, P., Opći dio kaznenog prava, Osijek, 2016.

23. Punoljetni počinitelji kaznenih djela - prijave, optužbe i osude u 2010., 2011., 2012., 2013., 2014., 2015., 2016., 2017. godini, Državni zavod za statistiku, URL=http://digured.srce.hr/webpac-hidra-pprh/?rm=results\&show_full=1\&f=IDbib\&v=SD010332. Pristupljeno 12. rujna 2018.

24. Sakoman, S.; Raboteg-Šarić, Z.; Kuzman, M., Raširenost zlouporabe sredstava ovisnosti među hrvatskim srednjoškolcima, Društvena istraživanja, god. 11, br. 2-3 (58-59), 2002., 311.-334.

25. The State of Drugs problem and in the European Union and Norway, European Monitoring Centre for Drugs and Drugs Addiction. Luxembourg: Office for Official Publications of the European Communities, 2003.

26. Tripalo, D., Kaznenopravni aspekti zlouporabe droga, Hrvatski ljetopis za kazneno pravo i praksu, Zagreb, god. 10, br. 2, 2003., 553.-585.

27. Turković, K.; Novoselec, P.; Grozdanić, V.; Kurtović Mišić, A.; Derenčinović, D.; Bojanić, I.; Munivrana Vajda, M.; Mrčela, M.; Nola, S.; Roksandić Vidlička, S.; Tripalo, D.; Maršavelski, A., Komentar Kaznenog zakona, Narodne novine, 2013., Zagreb.

\section{MREŽNE STRANICE:}

1. Izvješće o provedbi Nacionalne strategije i Akcijskog plana suzbijanja zlouporabe droga u RH za 2016. godinu, Vlada RH, USZD, Zagreb, 2017., URL=https://drogeiovisnosti.gov.hr/pristup-informacijama/strategije-planovi-i-izvjesca/izvjesca-o-provedbi-nacionalne-strategije-i-akcijskih-planova/940. Pristupljeno 22. kolovoza 2018.

2. Nacionalni program - Suzbijanje zlouporabe droga, Ministarstvo unutarnjih poslova Republike Hrvatske. URL=https://www.mup.hr/public/documents/Nacionalni\%20programi/Nacionalni\% 20program\%20-\%20Suzbijanje\%20zlouporabe\%20droga.pdf. Pristupljeno 14. srpnja 2018.

3. Posjedovanje droge za osobnu uporabu prekršajno, a ne kazneno djelo. URL=https://pravosudje. gov.hr/posjedovanje-droge-za-osobnu-uporabu-prekrsajno-a-ne-kazneno-djelo/6388. Pristupljeno 11. veljače 2019.

4. Posjedovanje ili prodaja: koliko grama teži osobna uporaba?, URL=http://www.novilist.hr/ Vijesti/ Hrvatska/Posjedovanje-ili-prodaja-Koliko-grama-tezi-osobna-uporaba?meta-refresh=true. Pristupljeno 13. srpnja 2018.

5. World Drug Report 2018., URL=https://www.unodc.org/wdr2018/prelaunch/Pre-briefingAMfixed.pdf. Pristupljeno 10. srpnja 2018.

\section{ZAKONI I DRUGI AKTI:}

1. Kazneni zakon iz 1997. Narodne novine, broj 110/1997, 27/1998, 50/2000, 129/2000, 84/2005, 51/2001, 111/2003, 190/2003, 105/2004, 71/2006, 110/2007, 152/2008, 57/2011, 77/2011, $125 / 2011,143 / 2012$. 
2. Kazneni zakon, Narodne novine, broj 125/2011, 144/2012, 56/2015, 61/2015, 101/2017, $118 / 2018$.

3. Konvencija za zaštitu ljudskih prava i temeljnih sloboda te Protokola br. 1, Protokola br. 4, Protokola br. 6 te Protokola br. 7 uz tu Konvenciju, Narodne novine - Međunarodni ugovori, broj 6/1999.

4. Krivični zakon SFRJ, Službeni list SFRJ, broj 44/1976, 36/1977, 56/1977, 34/1984, 74/1987, 3/1990, 38/1990.

5. Okvirna odluka Vijeća 2004/757/PUP od 25. listopada 2004. o utvrđivanju minimalnih odredaba vezanih za elemente kaznenih djela i sankcija u području nezakonite trgovine drogom, SL L 335, 11. 11. 2004.

6. Pravilnik o izmjenama i dopunama Pravilnika o mjerilima za razvrstavanje lijekova te o propisivanju i izdavanju lijekova na recept, Narodne novine, broj 86/2013, 90/2013, 102/2014, 107/2015, 72/2016

7. Prekršajni zakon Narodne novine, broj 107/2007, 39/2013, 157/2013, 110/2015, 70/2017, 118/2018.

8. Prijedlog zakona o izmjenama i dopunama Kaznenog zakona, Ministarstvo pravosuđa, Zagreb, listopad 2012.

9. Ustav Republike Hrvatske, Narodne novine, broj 56/1990, 135/1997, 113/2000, 28/2001, 76/2010, $5 / 2014$.

10. Zakon o preuzimanju Krivičnog zakona Socijalističke Federativne Republike Jugoslavije, Narodne novine, broj 53/1991.

11. Zakon o provedbi uredbi Europske unije iz područja prekursora za droge, Narodne novine, broj $80 / 2013$

12. Zakon o sigurnosti prometa na cestama, Narodne novine, broj 67/2008, 48/2010, 74/2011, 80/2013, 158/2013, 92/2014, 64/2015, 108/2017.

13. Zakon o sprječavanju nereda na športskim natjecanjima, Narodne novine, broj 117/2003, 71/2006, 43/2009, 34/2011.

14. Zakon o suzbijanju zlouporabe opojnih droga, Narodne novine, broj 107/2001, 87/2002, 163/2003, 141/2004, 40/2007, 149/2009, 84/2011, 80/2013, 39/2019.

\section{ODLUKE SUDOVA:}

1. Europski sud za ljudska prava, A. i B. protiv Norveške, zahtjev 24130/11 i 29758/11 od 15. studenog 2016.

2. Europski sud za ljudska prava, Engel i drugi protiv Nizozemske, 5100/71; 5101/71; 5102/71; 5354/72; 5370/72, 8. lipnja 1976.

3. Europski sud za ljudska prava, Öztürk protiv Njemačke, 8544/79, 21. veljače 1984.

4. Europski sud za ljudska prava, Ezeh i Connors protiv Ujedinjenog Kraljevstva, 39665/98 i 40086/98, 9. listopada 2003.

5. Europski sud za ljudska prava, Maresti protiv Hrvatske, zahtjev 55759/07, 25. lipnja 2009.

6. Europski sud za ljudska prava, Tomasović protiv Hrvatske, zahtjev 53785/09, 18. listopada 2011.

7. Županijski sud u Bjelovaru, Kž-182/2016, 17. studenog 2016.

8. Vrhovni sud Republike Hrvatske, I Kž 60/12-7, 27. studenog 2014. 
9. Rješenje Visokog prekršajnog suda. Rješenje Jž - 2490/14, 31. ožujka 2015.

10. Rješenje Visokog prekršajnog suda Jž-3608/2012, 10. travnja 2014.

11. Rješenje Visokog prekršajnog suda broj Jž-4411/2013, 9. travnja 2014.

12. Prekršajni sud u Bjelovaru, Pp J- 830/17-19 od 22. prosinca 2017.

13. Prekršajni sud u Bjelovaru, Pp J-22/17-44 od 13. travnja 2017.

14. Prekršajni sud u Bjelovaru, Pp J-631/17-17 od 7. prosinca 2017.

15. Prekršajni sud u Bjelovaru, Pp J-498/17-12 od 31. kolovoza 2017.

16. Prekršajni sud u Bjelovaru, Pp J-91/17 od 21. rujna 2017.

17. Prekršajni sud u Bjelovaru, Pp J-496/17-12 od 3. studenog 2017.

18. Prekršajni sud u Bjelovaru, Pp J-217/18-12 od 28. svibnja 2018.

19. Prekršajni sud u Bjelovaru, Pp J-805/17-18 od 18. siječnja 2018.

20. Prekršajni sud u Bjelovaru, Pp J-428/17-10 od 8. lipnja 2017.

21. Prekršajni sud u Bjelovaru, Pp J-183/16-10 od 15. ožujka 2016.

22. Prekršajni sud u Bjelovaru, Pp J-324/17-24 od 3. srpnja 2017.

23. Prekršajni sud u Bjelovaru, Pp J-134/18-10 od 7. lipnja 2018.

24. Prekršajni sud u Bjelovaru, Pp J-922/17-9 od 27. ožujka 2018.

25. Prekršajni sud u Bjelovaru, Pp J-232/18-11od 14. lipnja 2018.

26. Prekršajni sud u Bjelovaru, Pp J-897/16-9 od 7. prosinca 2016.

27. Prekršajni sud u Bjelovaru, Pp J-833/16-8 od 3. veljače 2017.

28. Prekršajni sud u Bjelovaru, Pp J-271/15-20 od 10. studenog 2015.

29. Prekršajni sud u Bjelovaru, Pp J-438/15-8 od 16. ožujka 2016.

30. Prekršajni sud u Bjelovaru, Pp J-46/18-9 od 8. svibnja 2018.

31. Prekršajni sud u Bjelovaru, Pp J-368/16-11od 7. lipnja 2016.

32. Prekršajni sud u Bjelovaru, Pp J-875/17-13 od 8. studenog 2017.

33. Prekršajni sud u Bjelovaru, Pp J-610/17-10 od 25. srpnja 2017.

34. Prekršajni sud u Bjelovaru, Pp J-572/17-11, 4. rujna 2017.

35. Ustavni sud Republike Hrvatske, U-II/4038/2015, 11. srpnja 2017. 


\section{MISDEMEANOUR LAW AT THE SERVICE OF DRUG SUPPRESSION IN THE REPUBLIC OF CROATIA: DRUG POSSESSION WITHOUT DISTRIBUTION INTENTION}

\section{Summary}

When it comes to drug abuse suppression, the choice of a state reaction is conditioned by different circumstances, but the aspiration for efficiency is the primary motive. The means of banning imply legal mechanisms and sanctions, and in the Republic of Croatia, these mechanisms derive from criminal law and misdemeanour law. The subject of this paper focuses on the misdemeanour law in view of the significant alteration presented in the Republic of Croatia a few years ago: drug possession without distribution intention has been left out of criminal law mechanism and left to misdemeanour law. However, this solution opens a number of questions. The paper gives answers to these questions by a holistic approach. It presents the legislative positions, taking into account the prior knowledge and the etiology of the accepted solution, outlines the presence of drug abuse in the society, and by conducting research of relevant judgments, the paper discloses the attitudes of the judiciary by reviewing the adequacy of the adopted solution.

Keywords: $\quad$ Drug abuse, misdemeanour law, possession of drugs without distribution intention, misdemeanour sanction, criminal law

\section{(c) (1) (9)}

This work is licensed under a Creative Commons

Attribution-NonCommercial 4.0 International License.

\footnotetext{
Barbara Herceg Pakšić, PhD, Assistant Professor, Faculty of Law, University of Josip Juraj Strossmayer in Osijek, Stjepana Radića 13, 31000 Osijek, Republic of Croatia. Email address: bherceg@pravos.hr. ORCID: https://orcid.org/0000-0002-7052-928X.

** Nikolina Kovač, mag. iur., Borisa Papandopula 36, 43000 Bjelovar, Republic of Croatia. Email address: nikolina.kovac121@gmail. com. ORCID: https://orcid.org/0000-0001-5549-4579.
} 